\title{
PORT AUTHORITIES IN THE UNITED STATES
}

\author{
Marvin L. Fair*
}

The public port authority has come to play a dominant role in the administration of the ports of the United States. As municipalities and states became vitally interested in the development of their ports as gateways to commerce, they reached out for a more effective administrative device to finance, plan, and develop facilities and to administer the port in the interest of the entire community. A quasi-independent public port authority outside the framework of conventional government departments became the preferred administrative device of the many seaports of the nation. Airport administration is following a similar line of development. Indeed, as we shall see, some communities have put airport administration under the existing port authority.

\section{I}

\section{Evolution of Port Concept}

The employment of the public authority with broad responsibilities came about in this country, as it had earlier in Europe, as the result of the evolution of the concept of a port. The term "port" is derived from the old Latin term "porta" meaning a gate or gateway. From ancient times a seaport has been recognized as a gateway to the city and country which it serves. As this author has observed elsewhere, a port is not just a collection of physical facilities in a harbor area but essentially a community enterprise whose nature is largely shaped by the community's conception of what the port is or should be. A survey of the types of administrative organizations in the various localities of the United States and elsewhere reveals an impressively wide range in the concept of a port. ${ }^{1}$

The elementary concept of the port is that of a public highway. To this end a city would pass ordinances designed to assure free and equitable access for all persons of the community who sought to use the port for legitimate purposes. An interesting early example was a Philadelphia ordinance of 1803 which states: ${ }^{2}$

It is held that free entrance to, and passage over all piers, wharves, and buildings which extend into the stream beyond the low water mark of any navigable stream in the City of Philadelphia is a public right. Such structures may be used by all persons, drays, carts, etc., desiring to pass over them for the purpose of reaching either river, shore, or any vessel that may be moored to any structure. No owners or tenants of such structures nor their local representatives have any authority to obstruct or prevent the use of such structures as

- A.B. 1923, Ohio University; M.A., Ph.D. 1930, Ohio State University. Professor of Business Administration and Transportation, and Director of the Transportation Program, The American University, Washington, D.C. Author, Port Adninistration in the UNITED States (1954); co-author with E. W. Williams, Economics of Transportation (rev. ed. I959).

${ }^{1}$ Marvin L. Farr, Port Administration in the United States 4 (I954).

${ }^{2}$ Act of March 29, $1803, \S \times 2$, passed by the County of the City of Philadelphia. 
passageways for the purpose as described above. . . Such owners and tenants, or their local representatives, have the right, however, to require persons desirous of using these structures as passageways, to proceed directly across the same, and after transacting their business thereon to leave the premises promptly.

The highway concept evolved into what one might term a utility concept. This contemplates an investment in a waterfront plant which serves a public use, essential to the economic progress of the community. Equal access to shippers and carriers on the land side and adequate accommodation to all vessels desiring to enter for loading or unloading became the prime objectives.

In the broadest sense a public port authority is a public body established by law to have specific powers over all or part of a port or port area with specific powers to act with respect to a definitive area of responsibility. As the concept of a port evolved to what might be called a public business enterprise, the port authority became a body with comprehensive powers relative to the entire port area. No longer could the port be considered a collection of independent enterprises under a very limited degree of control of some local agency which was not staffed for necessary technical and financial responsibilities. In this context the port becomes an important financial enterprise with a special business service function to perform in the provision of and operation of a set of related port facilities, and an administration with broad powers to finance development of the port by improved and coordinated facilities.

In spite of its late development in this country, port administration is not new. The public importance of the port gateway was recognized by the earliest maritime nations. Ancient Carthage, for example, in addition to its natural harbor of the Lake of Tunis, had two landlocked basins which the city state had constructed. The outer square-shaped basin served the commerce of the state while the inner circular-shaped one accommodated naval craft. An admiral stationed in a tower controlled operations in the basin areas. ${ }^{3}$ Special officers were appointed to supervise and control payments to the sellers of merchandise who had received guarantees from the state. 4

Medieval city states, including Genoa and Venice, established some form of public authorities which administered maritime law and supervised the loading and unloading of vessels. ${ }^{5}$ The dominance of city states of Italy and the Hanseatic towns in the maritime commerce of late medieval and early modern times resulted in the establishment of autonomous free ports. Local administration of these yielded reluctantly to the rise of nation states and submission to a degree of national control. The prevailing pattern of control of the major ports of the European continent today is that while the national government participates in the providing of channels and quays, the local municipality or municipalities administer the port's operations.

\footnotetext{
${ }^{8}$ R. Bushworth Smith, Carthage and the Carthagenians $353-55$ (1916).

'A. H. L. Heiren, Historical Researches Into the Politics, Intercourse, and Trade of the Carthagentans, Ethioptans, and Egyptiañs 157.58 ( 1838 ).

${ }^{5}$ M. P. Charlesworth, Trade Routes and Commerce of the Roman Empire 42 (2d ed. 1926).
} 
The port director, often appointed for life, may report to the city board of aldermen. or to a special governing board whose members represent both government andi business.

\section{II}

\section{DeVELOPMENT IN THE UNITED States}

It is not apparent that experience on the continent has substantially influenced theAmerican experience. Until the last quarter of the nineteenth century, the port cities. of the United States were groping their own way as had the earliest maritime cities: of the Mediterranean two thousand years before. It was only after the concept of theport had developed in some American ports that the significance of the British experience in this area during the last century attracted attention. Local city control developed in some British ports and became a model for early municipal authorities. In these, the port warden, or director of the public wharf or wharves, was considered an integral part of the city government. ${ }^{6}$ However, it was the successs of the public corporation at the ports of Liverpool and Glasgow (1858) ${ }^{7}$ and later at London and: Manchester which encouraged the employment of the public corporation as a type: of port authority in the United States. The extensive autonomy of the British port. authorities and their divorce from local politics made these ports exemplary in. the field of port administration.

A comparable movement did not take place in the United States until the present century. Public administration had been largely confined to that of a harbormaster or wharfinger who was appointed by the state or municipality. Only fourport authorities having broad powers were established in the nineteenth century, namely: the Board of State Harbor Commissioners of the San Franciso Harbor, 1863; the Department of Docks, now known as the Department of Marine and Aviation of the City of New York, I870; the Department of Wharves, Docks and Ferries. of Philadelphia, $1885 ;^{8}$ and the Board of Commissioners of the Port of New Orleans, I896.

Other ports continued to rely upon the federal government for channel developments, and on private interests for waterfront facilities. Railroads, sail boat lines, steamship companies, independent dock companies, and waterfront industries provided almost all of the waterfront facilities. During the second half of the last: century, the railroads came to dominate most of the leading ports with their waterfront trackage and docks.

By the end of the first decade of the twentieth century, the modern port administration movement began; and by the mid-twenties, it had attained substantial:

\footnotetext{
among these ports were Southampton, Hull, and Bristol. The last is the principal British port to retain "city hall" administration. A committee of the city council usually administers the port.

${ }^{7}$ In 1858 , the port of Liverpool was placed under the administration of the Mersey Docks and Harbor Board; and the port of Glasgow established the Trustees of the Clyde Navigation.

${ }^{8}$ Philadelphia by 1803 had provided a public wharf and had established the concept of the port as an public enterprise. See note 2 supra. Nevertheless, a separate department was not created until i $855 ;$ and a director of the department was not provided for until Igrr.
} 
momentum. An increasing number of ports came to realize what the cities of San Francisco, New Orleans, Philadelphia, and New York realized earlier, that private interests could not be relied upon to provide for the development of the port and its commerce. So long as the predominant character of a major railroad was that of a trunk line stretching into the interior from a single terminus with interest in a connecting steamship line, the railroads aggressively constructed waterfront facilities, and they provided what were then modern facilities for the transfer between ship and rail car. But near the end of the century, the principal railroads became multipleheaded systems serving two or more ports. Most of the major ports came to have two or more trunk lines, thus providing competition all along the seaboard, and destroying the single railroad-port identity of interest. In the second decade of the twentieth century, the Panama Canal Act of x914 prohibited railroad control of intercoastal lines. This resulted in general divorce of rail and steamship interest and control. The railroads no longer had the incentive to aggressively construct and improve waterfront facilities. Waterfront areas of the older ports declined from neglect in spite of growing foreign and coastwise trade. Intercoastal trade increased very rapidly after the completion of the Panama Canal in Igr6.

\section{III}

\section{Kinds of Port Authorities}

Public authorities which have administrative authority at the nation's seaports may be classified as (I) navigation agencies, (2) transportation agencies, and (3) port authorities proper.

Navigation agencies are the oldest of these. Ever since colonial times, it was not uncommon for the colony, state, or city to establish rules and regulations covering pilotage in harbor areas. Later, authority for selection of pilots was established in many states and localities. If the port is far inland, like New Orleans, Albany, or Chicago, there may be several pilotage areas involved, with pilots separately licensed for each section of the channel.

The states of Pennsylvania and North Carolina have navigation agencies which have broad authority over navigable channels of the state. In Pennsylvania, the agency is the "Navigation Commission for the Delaware River and Its Navigable Tributaries." It was established in 1907, and on the basis of the long history of its predecessor, the Board of Port Wardens established by the colony of Pennsylvania in 1763 , claims to be the oldest port authority in the United States. The Act of 1907 extended its authority over pilots and pilotage. This Board, as part of the Department of Forests and Waters, is a state agency, although the mayor and port director of the Port of Philadelphia are ex officio members of the seven man board. For all the river and its tributaries, the Board may (I) make rules for the regulation, stationing and anchoring of vessels in the channel or at docks to assure adequate room for passing of vessels and access to berths; (2) impose fines upon violators of its regulations with respect to dumping of refuse in navigable channels; (3) remove vessels 
sunk or stranded after ten days' notice to the owner and at his expense; (4) select port wardens for the ports of Boston, Philadelphia and Chester; and (5) establish regulation for pilotage and select qualified pilots. Philadelphia as a first-class city is largely independent of the board with respect to these powers, especially the first three. Outside of Philadelphia, the board requires permits for construction or alteration of waterfront facilities.

The North Carolina Board of Commissioners of Navigation and Pilotage selects port wardens, and administers pilotage regulation and appointments. It handles disputes between pilots and masters of ships.

The transportation authorities, which administer bridges, tunnels, ferries, and airports, may include water port administration. They are found in metropolitan New York, Philadelphia, and St. Louis. They are transportation agencies of a broad character, going far beyond the jurisdiction over waterfront port development and management. Such transportation authorities are not to be confused with transit authorities, because they do not operate transit or commuter passenger services. Rather, they are transportation facility authorities. Although several of the more conventional port authorities have jurisdiction over bridges, ferries, highways in the port area, terminals, and airports, this jurisdiction is secondary to the responsibility for waterfront port administration.

The metropolitan transportation authorities are all bi-state public corporations. This type of authority cuts across the barrier of state and local political units, and permits orderly planning and development of the port and other transportation facilities of the metropolitan area. Their creation requires the enactment of parallel legislation of participating states, and the execution of a compact between the states which must be approved by the Congress of the United States. As corporations, they are able to acquire, lease, borrow, construct, and operate facilities. They collect and spend their own revenue, and may float their own securities.

The governing board is made up of an equal number of commissioners appointed by the respective governors of the participating states. The three port authorities in this category include: the Port of New York Authority; the Delaware Port Authority; and the Bi-State Development Agency which functions in the St. Louis-East St. Louis area. All have essentially the same legal characteristics.

The Port of New York Authority, established in rg2r, not only set a precedent for a multi-state authority but also instigated the trend to the public corporation in seaport administration. It grew out of an extensive and intensive study of a New York and New Jersey Joint Commission which was concerned with growing congestion in the traffic pattern of the city of New York and environs. Congestion involving highways, ferry boats, and rail operations was increasing to the point that the trade of the port and even the local trade activities of the city were threatened with increasing cost and paralysis. The Port Authority, at the outset of its operation, actually had no waterfront jurisdiction except for a few unimportant barge facilities at the East River. Until the postwar period, when by a long term lease the 
Authority acquired responsibility for the Port of Newark, and by a similar long iterm lease, control over the municipal airports of the metropolitan area, the Port Authority had remained essentially a bridge and tunnel authority. More recently, it has acquired additional waterfront facilities at Hoboken and Brooklyn. The cityowned waterfront facilities, located largely on Manhattan, have remained in the direct control of the city government, and are administered by the Department of Marine and Aviation.

The Delaware River Port Authority similarly has been excluded from direct jurisdiction over the waterfront facilities of the city of Philadelphia and of Camden because of the desire of the established governments of these cities to retain control and administration. The principal work of this authority relates to bridges over the Delaware River in the harbor area. Both the New York and Delaware River Authorities carry on promotional activity in behalf of the metropolitan seaport where they are located.

The Bi-State Development Agency of the St. Louis area goes beyond the planning and development of transportation facilities and includes the development of drainage, sewage, water supply, recreational facilities, and land use pattern for the district. This authority, unlike the New York and Delaware River authorities, has no income from bridges and tunnels, and because of inadequate appropriations has been unable to finance extensive improvements.

\section{IV}

\section{Waterfront Port Authorities}

\section{т. Functions}

These are the conventional port authorities. Their jurisdiction is largely confined to the harbor, the waterfront facilities, and the marginal rail trackage, highway facilities, and storage facilities that constitute an ocean port. A few, including the ports of Houston, Texas, and Stockton, California, administer channels extending beyond the harbor area. The tasks performed by these port authorities vary widely; and hardly any two exercise precisely the same functions. This variation arises from differences in legal attributes, conflict of authority with other units of government in the harbor area, or simply from unwillingness to assert full legal powers. The functions that are performed by the majority of these authorities include:

dredging of slips and areas which are not maintained by the Corps of Engineers; maintenance of publicly-owned waterfront facilities;

establishing and collecting of charges at publicly-owned facilities; lease of facili-

ties; maintenance of statistics in regard to port traffic and finance;

promotion of traffic and trade through the port;

purchase of the land and facilities required for the development of the port; exercise of the right of eminent domain;

preparation of plans for the development and coordination of facilities;

construction of needed facilities; 
assignment of berths at publicly-owned facilities;

maintenance of accounting and preparation of financial reports which must be submitted to some government official or office;

promotion of public relations;

raising capital for improvement;

purchasing, developing and leasing industrial sites.

The power to exercise the right of eminent domain to acquire waterfront properties is frequently granted by law, but is often circumscribed to some extent by the requirement of approval of city or state officials, or the exemption of carrier owned facilities.

Port authorities are inclined to be cautious in the exercise of their power although its generous use may offer the only hope of an orderly and continued development of coordinated operations at the port.

The functions which are exercised by only a minority of port authorities include:

regulation of privately-owned terminals in the port area with respect to rates, and maintenance in terms of keeping docks clean and in good order;

maintenance of harbor police;

ownership and use of harbor craft including fire boats, dredges, barges, lighters, and inspection boats;

regulation and/or operation of bridges, ferries and/or tunnels;

ownership and regulation of public belt railroads;

operation of public belt railroads;

regulation of pilotage, including the licensing of pilots;

licensing and regulating of stevedores;

selection and control of the harbor master;

control of harbor traffic;

performance of complete terminal operation, including stevedores;

general cargo terminal operation.

Of the functions which a port authority may perform, the most rare is that of complete terminal operations where the port authority performs all operational steps including stevedoring between inland carrier and the ship.

\section{Types of Port Authorities}

In terms of political units involved, the port authority may be identified with local governments (municipal or county), or with a district made up of portions of two or more municipalities or counties, or it may be an agency within the general framework of state government. Previously we have observed that transportation authorities, in the three instances described, are each identified with two state governments. Approximately two thirds of the waterfront port authorities are local authorities, that is, municipal, county, or district agencies, while a little over one third come under the category of single state agencies. During the last fifteen years, 
there has been a definite trend from local to state status. Several ports, during this time, have come under newly established state or bi-state authorities while retaining local authorities for certain functions. The ports in Georgia and Virginia and of Philadelphia and Camden are among these.

In this paper, our primary concern relates to the types of port authority in terms of organization and legal status. For this purpose, public port authorities may be classified as follows: (I) the government departmental agency, local or state, which may be either the executive or commission type; (2) commissions which are (a) elective, or (b) appointive; (3) advisory commissions; and (4) public corporations, bi-state, state, or local, the members of the board of which may be (a) elective, (b) appointive from nominations, or (c) appointive without nominations.

The principal considerations of organization are the political unit or units which appoint the members of the board that constitutes the port authority; and the sources of financial support of the port. Normally, the same political unit that is responsible for appointments to the board is also identified with the financial support of the port. However, occasionally a governor may be empowered to appoint at least some members of a local port authority although the sole financial support is provided by a city, county, or district. This arrangement seldom proves practical and is likely to give way to a more effective identity of appointive power and financial support. At Duluth, although the port authority is a state corporation, some of its members are appointed by local officials.

a. Departmental Authorities. Among the organizational types, the one dominant in the United States prior to the twentieth century was the municipal department, set up like any other city department. The continued prevalence of this type of authority in the twentieth century was probably made possible by the fact that the federal government, acting through the U. S. Army Corps of Engineers, early in the nineteenth century took over the responsibility for the construction and maintenance of harbor channels. We have previously observed the extensive initiative of the railroads in building waterfront facilities prior to I915. At the Eastern ports and at Seattle, Washington, the railroads serving the ports were collectively the principal port authorities. However, with the advent of public activity in port improvement and administration, the city departments as intimate parts of the city hall administration and politics rapidly gave way to commissions-usually of the independent variety (with a few commissions set up to administer existing city departments) and to the public corporation, either local or state. Except for the municipal waterfront facilities of New York, and Philadelphia, Chicago, and Jacksonville, this type of government organization is virtually extinct. The departmental agency may be the executive or commission type. These city departments vary widely in organization and functions. At Milwaukee, Miami, and Muskegon, a commission administers the city or county department.

The only authority which might be considered a state departmental authority is the former Port of Boston Commission (until 1953, the Port of Boston Authority). 
This organization, which was replaced by the Massachusetts Port Authority created in 1956 , was of the commission type but functioned as a department of the Commonwealth in its relations to the governor and legislature, just as truly as the Board of Harbor Commissioners of the city of Milwaukee is a department of the city government.

The independent commission by IgIo had established itself as the prevailing type of independent agency to regulate transportation and public utilities at both the state and federal levels. It is not surprising that it became popular between rgro and I925, when the trend toward the public corporation got under way. This, therefore, was the first major effort to set up a responsible body essentially removed from the currents of partisan politics; and to provide an agency with adequate jurisdiction and authority to construct facilities, promote the port, and administer its operations in the interest of the whole community. Members of a commission are usually appointed by the mayor or city manager with the approval of the city council, selected by the county board of supervisors, or appointed by the governor and confirmed by the governor's council or state senate. An exception is found at Port Everglades, Florida, where the members of the port district commission are elected by voters of the port district. Other ports administered by local commissions are Astoria and Port Angeles, Washington; Corpus Christi and Houston, Texas; Detroit, Michigan; Fort Pierce, Florida; Long Beach, Oakland, San Diego, and Redwood City, California; St. Paul, Minnesota; and Memphis, Tennessee. Among the independent state commissions are those governing the ports of San Francisco, Hawaii, and Mobile.

Conforming to the general pattern of the regulatory commission, the terms of port commissioners are generally staggered, and they are appointed for a period exceeding the tenure of elected officials. These commissions may be given extensive powers, broadly including the functions listed previously. However, unlike the public corporation, the independent commission does not have the right to sue and be sued, to use a corporate seal, and to issue securities under its own name.

b. Public Corporations. The establishment of the Port of New York Authority in I92I received extensive publicity throughout the county, and apparently ushered in a trend toward the public corporation as the preferred type of port authority. The public corporation, like any corporation, is an entity for all legal purposes, and as such, its actions are essentially independent of the political units of state or local government which created it. However, it is not entirely autonomous since it is necessarily subordinate to the establishing government as a whole, and especially to the chief executive and legislative body of the state in which it is located. States can, therefore, place some limits on the authority granted in the articles of incorporation, and certain designated actions may be subject to veto by the chief executive or legislature. The public corporation, nevertheless, affords a wide range of latitude of administrative action, and provides maximum insulation from currents of partisan politics. The public corporation as a port authority enjoys substantial advantages in 
its freedom to plan and construct improvements of the port. It has complete jurisdiction over its own revenues, which it may collect from the operation of port facilities and other facilities such as bridges, tunnels, and airports. This financial independence, combined with the flexibility of action which independent legal status provides, makes possible a program of continued improvement of the port by the port administration. Port authorities lacking this independence and flexibility may experience much frustration in carrying out plans for improvement, dependent as they are on the generosity of state legislators, county commissions, or city councils.

There are twenty-one local port corporations. They govern the following ports:

Albany, New York
Beaumont, Texas
Brownsville, Texas
Brunswick, Georgia
Coos Bay, Oregon
Galveston, Texas
Long View, Washington
Los Angeles, California
Monroe, Michigan
Norfolk, Virginia
Orange County, Texas

\author{
Oswego, Michigan \\ Pensacola, Florida \\ Raymond, Washington \\ Rochester, New York \\ Savannah, Georgia \\ Seattle, Washington \\ Tacoma, Washington \\ Tampa, Florida \\ Vancouver, Washington \\ Waukegan, Illinois
}

These corporate bodies are all administered by Boards of Commissioners. In most instances, the commissioners are appointed by the local authority, municipality, or county. However, eight Boards are elected by the electors of the port districts. These are located at: Beaumont, Brownsville, and Orange County, Texas; and Long View, Raymond, Seattle, Tacoma, and Vancouver, Washington.

There are now twelve state corporate port authorities. They include the South Carolina State Ports Authority; the Georgia Ports Authority; the Virginia State Ports Authority; the Greater Baton Rouge Port Commission; the Lake Charles Harbor and Terminal Department, Louisiana; the Board of Harbor Commissioners of the Port of New Orleans; the South Jersey Port Commission; the North Carolina State Ports Authority; the Main Port Authority; the Maryland Authority; the Massachusetts Port Authority; and the Port Authority of Duluth. All of these corporate authorities are governed by boards of commissioners who are appointed by the Governor of the state, except for the Port of Duluth, where local authorities appoint a majority of the members. At New Orleans and Baltimore, the Governor selects appointees from among nominees. In New Orleans nominations are made by the New Orleans Clearing House, the New Orleans Chamber of Commerce, the New New Orleans Cotton Exchange, the New Orleans Board of Trade, and the New Orleans Steamship Association. Each of these five organizations submits the names of two nominees to the Board of Commissioners of the Port of New Orleans. The 
board selects three of the ten as nominees and forwards the list to the Governor for one appointment to fill a vacancy.

In Baltimore, the Governor selects five commissioners from a slate of fifteen nominated ratably by the Board of County Commissioners of Anne Arundel County, the Mayor of Baltimore City, and the Board of Commissioners of Baltimore County. Unusual is the Maryland statement of personal qualifications of board members, which reads, "The members of the authority shall be persons of ability, experience and integrity and shall not be selected as representing or supporting any special interest or interests." This contrasts sharply with the representation of commercial interests at New Orleans.

c. Multiple Port Authorities. Some harbors have multiple port authorities. This causes an overlapping of jurisdictions. It has been observed that the states of Virginia and Georgia have established corporate state authorities, but that local port authorities continue to function. South Carolina and North Carolina have truly centralized state corporate authorities which have complete jurisdiction of all seaports of the state. The port of New York has both the Port of New York Authority and the Department of Marine and Aviation; the port of Philadelphia has the Delaware River Port Authority and the City Department of Commerce; and the port of Camden is governed by the Delaware River Port Authority and the South Jersey Port Commission. While the state or regional authorities have waterfront administrative powers, these functions are in practice generally left to the municipal authority. The general authority may operate bridges, tunnels, and airports, and may limit its water port activities to promotion and development of the seaport.

\section{Trends in Type of Port Authority-Conclusion}

The table below sets forth the trend in the types of organizations of port authorities in the United States from I92I to I96I. In terms of newly established port authorities, it will be observed that as of $\mathrm{x} 92 \mathrm{x}$, the number was rather evenly divided between government departments, independent commissions, and public corporations, but that since I92r, except during the depression decade of the 1930's, the trend has been toward the public corporation. During this decade, more independent commissions than public corporations were established, perhaps because public corporations, like private corporations, experienced difficulty in floating securities. There is now a trend toward state authorities. In fact, most of these are of postWorld War II origin, the most recent ones being those of Virginia, Maryland, Mississippi, and Massachusetts.

\footnotetext{
' 1950 amendments to Maryland Port Authority Act, MD. Code ANn. art. 62B, $\$ 3$ (c) (I957).
} 
Number of Port Authorities by Type, ig2i, and Created in Subsequent Periods Distribution of authorities established

Government by I921 I92I-I930 I931-I940 I94I-I950 I95I-rg6I

Departments

I

7

Commissions

Public

Corporations
2

8
7 5

3

I

5

3

5

3

Io

9

The use of port authorities in the United States was meager before rgro but has developed rapidly since that time. These authorities have increased in number and improved in structure. Public corporations have multiplied in this area, as they provide for more autonomous and adequate jurisdiction for development and operation. The aggregate of experience in the development of port authorities by ports of the United States is impressive. However, a substantial degree of politics, local or partisan, remains, with the result that the Directors or Managers usually have brief tenure and, therefore, seldom are trained professional port administrators. In other words, our political tradition has not kept pace with advances in the legal structure of port administration. 